\title{
Peran Gereja dalam Memberdayakan Penyandang Disabilitas di Gereja Toraja Jemaat Kaero
}

\section{Devi*, Ivan,Frans Paillin Rumbi \\ Institut Agama Kristen Negeri Toraja \\ *devidelpiana@yahoo.com}

\begin{abstract}
This paper explains congregation understanding about people with disabilities and how the church empowers them. This paper using a qualitative method with the inductive approachdata sources from literature research, observations, and interviews. The findings of this research are people with disabilities were very difficult to accept the situation. However, the people with disabilities can rise and think positively after getting mentoring from church. Chruch assembly to organize service programs like material help and pastoral care, and then empowers. Now, people with disabilities will be getting self-sufficient and participate in serving the church.
\end{abstract}

Keywords: service, church, empowerment, and disability

\begin{abstract}
Abstrak : Tulisan ini bermaksud menjelaskan pemahaman jemat tentang penyandang disabilitas serta bagaimana gereja memberdayakan para penyandang disabilitas. Data-data dikumpulkan melalui studi kepustakan, observasi dan wawancara. Hasil penelitian ini menemukan bahwa penyandang disabilitas awalnya sulit untuk menerima keadaannya. Akan tetapi mereka dapat bangkit dan berpikir positif karena mendapat pendampingan dari gereja. Majelis gereja menggiatkan program diakonia baik berupa bantuan materi, pendampingan pastoral dan pemberdayaan. Kini penyandang disabilitas mulai menjadi pribadi yang mandiri dan terlibat aktif dalam pelayanan.
\end{abstract}

Kata kunci: Diakonia, Gereja, Pemberdayaan dan Penyandang Disabilitas

\begin{tabular}{llll}
\hline Article History : & Received: 11-06-2021 & Revised: 30-07-2021 & Accepted:30-07-2021 \\
\hline
\end{tabular}

\section{Pendahuluan}

Dalam Undang-undang RI No. 8 Tahun 2016 Pasal 1 ayat 1 menjelaskan definisi dan ruang lingkup penyandang disabilitas yakni merujuk kepada mereka yang tebatas secara fisik, intelektual, mental, dan atau sensorik dalam jangka yang lama. Pada ruang interaksi sosial penyandang disabilitas seringkali diperhadapkan dengan keterbatasan untuk terlibat aktif, maupun karena adanya sikap diskriminatif dari orang lain. Sementara itu, Thohari berpendapat bahwa penyandang disabilitas merupakan orang yang memiliki kelainan baik itu fisik maupun mental sehingga hal ini dapat mengganggu dalam menjalani kehidupan selayaknya, sulit berpartisipasi dengan lingkungan sekitar. ${ }^{1}$

${ }^{1}$ Slamet Thohari, "Pandangan Disabilitas Dan Aksesibilitas Fasilitas Publik Bagi Penyandang Disabilitas Di Kota Malang," Indonesian Journal of Disability Studies 1, no. 1 (2014): 27-37, accessed June 2, 2021, https://ijds.ub.ac.id/index.php/ijds/article/view/38. Hal 31 
Lebih lanjut, pada ayat selanjutnya dari pasal 1 (ay. 2 \& 3) dari UU No. 18 diungkapkan beberapa indikator sikap dan perlakuan yang dialami oleh penyandang disabilitas, antara lain: kurangnya akses layanan serta diskiriminasi terhadap kaum disabilitas. Perlakuan demikian memang masih sering terjadi, keterbatasan menjadi dasar penilaian orang lain dalam menempatkan mereka sebagai yang lemah dan tak berdaya. Atas dasar itu, upaya mengubah penilaian masyarakat, menjadi prioritas dalam usaha mengangkat harkat dan martabat penyandang disabilitas. Perubahan penilaian dapat memberi ruang yang lebih luas supaya ruang penerimaan kepada mereka di ranah publik menjadi semakin luas. Berdasarkan pra paham tersebut, maka penulis hendak mengetahui pemahamaan penyandang disabilitas tentang dirinya? serta bagaimana Gereja Toraja jemaat Kaero memberdayakan penyandang disabilitas? Hemat penulis, penyandang disabilitas harus diangkat menjadi subjek yang berdaya guna, bukan objek pemberdayaan. Untuk sampai pada idealisme tersebut, maka dibutuhkan kehadiran gereja yang memberdayakan jemaat, menawarkan berbagai ide kreatif yang dianggap dapat memberdayakan penyandang disabilitas. ${ }^{2}$ Pemberdayaan adalah jalan untuk menekan marginalisasi, diskriminasi serta memulihkan harkat dan martabat penyandang disabilitas di tengah masyarakat. Penelitian terhadap usaha pemberdayaan kaum disabilitas oleh institusi tertentu sudah sering dilakukan. Umumnya hal itu didasarkan pada keprihatinan terhadap kaum disabilitas. Misalnya penelitian, Muhammad Hidayat Noor terhadap lembaga pemberdayaan Yaketunis dan Yakkum. Penelitian tersebut mengkaji persamaan dan perbedaan dalam aksi pemberdayaan bagi kaum difabel. ${ }^{3}$ Yohanes Wele Hayon, menekankan perlunya gerakan kolektif dari berbagai kelompok partikular untuk menyikapi dan betindak terhadap penyandang disabilitas, bertolak dari teologi Katolik. ${ }^{4}$ Sy. Nurul Syobah meneliti keterlibatan penyandang disabilitas dalam usaha meningkatkan kesejahterannya. Hasil penelitian ini memperlihatkan bahwa para penyandang disabilitas belum banyak dilibatkan dalam program tersebut dan bahwa usaha yang dilakukan oleh pemerintah Kalimatan Timur belum mampu menjamin kesejahteraan mereka. ${ }^{5}$ Berbeda dengan penelitian tersebut, maka penelitian ini hendak mengkaji pandangan penyandang disabilitas tentang dirinya, kemudian mempertemukan penilaian mereka dengan upaya pemberdayaan yang dilakukan oleh gereja.

\section{Metode Penelitian}

Untuk menjawab tujuan penelitian, maka penulis menggunakan metode penelitian kualitatif dengan pendekatan induktif. Dalam penelitian induktif, peneliti bergerak dari

\footnotetext{
2 Innawati Teddywono, "Pemuridan Bagi Jemaat Penyandang Disabilitas," SANCTUM DOMINE: JURNAL TEOLOGI 10, no. 1 (December 29, 2020): 17-34, accessed June 2, 2021, http://sosbud.kompasiana.com/2014/06/14/disabil.

${ }^{3}$ Muhammad Hidayat Noor, “Agama Dan Pemberdayaan Difabel: Studi Komparatif Terhadap Yayasan Kesejahteraan Tunanetra Islam (Yaketunis) Dan Pusat Rehabilitasi Yayasan Kristen Untuk Kesejahteraan Umum (Yakkum)," Religi: Jurnal Studi Agama-agama XII, no. 1 (2016): 17-37.

4 Yohanes Wele Hayon, "Disabilitas Dalam Teologi Katolik: Dari Liberalisme Dan Politik Kaish," Inklusi: Journal of Disability Studies 6, no. 2 (2019): 235-258.

${ }^{5}$ Sy Nurul Syobah, "Pemberdayaan Penyandang Disabilitas Di Provinsi Kalimantan Timur," NUANSA: Jurnal Penelitian IImu Sosial dan Keagamaan Islam 15, no. 2 (December 18, 2018): 251-272, accessed June 2, 2021, http://ejournal.iainmadura.ac.id/index.php/nuansa/article/view/2057.
} 
mengenali konteks penelitian sebelum kemudian mendialogkannya dengan teori dan aksi. Pendekatan induktif dalam dunia teologi menggunakan model lingkaran pastoral. Usaha dimulai dari mengenali kenyatan sosial, kemudian menganalisisnya untuk mengenali permasalahan, selanjutnya mengkajinya dari analisis iman serta menentukan langkah praksis pastoral. 6 Dalam prosesnya penulis mengamati dan mewawancara beberapa orang terkait tema yang diteliti. Selanjutnya data yang diperoleh dari informan diolah secara deskriptif selanjutnya dianalisis

Subjek penelitian penulis yakni penyadang disabilitas dan majelis gereja (Pendeta, penatua, diakien). Penyandang disabilitas di Gereja Toraja Jemaat Kaero berjumlah lima orang, dimana empat orang menyadang disabilitas fisik, sedangkan satu orang menyandang disabilitas fisik dan mental. Penulis mengamati penyandang disabilitas terkait cara menjalani kesehariannya dan menjalin relasi dengan orang lain. Penulis melakukan wawancara kepada penyandang disabilitas ( 2 orang), dan tokoh-tokoh terkait (3 orang). Penulis mengajukan sejumlah pertanyaan berhubungan dengan persepsi penyandang disabilitas tentang dirinya, interaksinya dengan masyarakat sekitar maupun mencari tahu usaha-usaha yang dilakukan oleh gereja dalam memberi perhatian terhadap penyandang disabilitas.

\section{Hasil Penelitian dan Pembahasan}

\section{Pemahaman Penyandang Disabilitas Tentang Dirinya}

Dari tuturan penyandang disabilitas bernama Haris terungkap bahwa yang bersangkutan mengalami disabilitas fisik secara tiba-tiba (karena sakit). Kondisi ini pada pada awalnya memunculkan rasa penolakan terhadap keadaannya yang baru. ${ }^{7}$ Tampaknya faktor ketidaksiapan mental sangat dominan memengaruhi. Ketidaksiapan menerima perubahan kondisi dari seorang normal dan bebas beraktifitas, menjadi seorang yang terbatas secara fisik. Bersamaan dengan itu mendorong munculnya konsep diri negatif seperti sedih dan minder sehingga yang bersangkutan terpuruk dalam jangka waktu yang lama.

Cara menilai diri seperti itu dapat berakibat fatal karena dapat membuat penyandang disabilitas menjadi orang-orang yang pasif dalam lingkungannya. Dalam kondisi tersebut dibutuhkan keberadaan orang-orang di sekitar untuk membantu memulihkan dan mengubah cara memahami diri. Hal itulah yang ditempuh oleh majelis gereja melalui berbagai program pendampingan. Haris merasa bahwa aksi yang dilakukan oleh gereja adalah salah satu bentuk dukungan moril terhadap dirinya. Ia bisa mulai menerima kenyataan dan perlahan membuka diri untuk berpatisipasi dalam kegiatan yang dilaksanakan oleh gereja. 8

Pengalaman berbeda dituturkan oleh Jefry Huro yang mengalami cacat fisik sejak lahir. Sikap awal dari orang-orang disekitarnya yang sering mengejek dirinya, membuat

${ }^{6}$ J.B. Banawiratma, "Proses Teologi Sosial," in Aspek-Aspek Teologi Sosial, ed. J.B. Banawiratma (Yogyakarta: Kanisius, 1992), 11-15.

${ }^{7}$ Haris, "Wawancara Oleh Penulis" (22 April 2021).

8 Ibid. 
yang bersangkutan merasa minder dan seakan tidak diterima. Akibat perlakuan diskriminatif tersebut, Jefry mulai kehilangan kepercayaan dan penerimaan atas dirinya. Jefry sering merasa malu dan muda tersinggung. Sama seperti dengan Haris, Jefry akhirnya mengalami perubahan pola pikir setelah orang-orang di sekitarnya khususnya anggota keluarga terdekat dan gereja memotivasinya supaya tidak berkecil hati. ${ }^{9}$

\section{Pandangan Warga Jemaat Tentang Disabilitas}

Penyandang Disabilitas adalah orang yang tidak hanya kekurangan masalah fisik tetapi juga mental, karena biasanya orang hanya memandang dari fisik tanpa melihat keseluruhan, jadi penyandang disabilitas itu orang-orang yang memiliki kekurangan fisik dan juga mental. ${ }^{10}$ Penyandang Disabilitas adalah adalah orang yang memiliki keterbatasan fisik dan juga mental dalam berinteraksi dengan lingkungannya dan sulit berpartisipasi penuh dan efektif seperti orang-orang di sekitar yang normal.11 Penyandang disabilitas merupakan orang yang mengalami keterbatasan dalam melaksanakan aktivitas sosial baik secara fisik, intelektual, maupun mental. ${ }^{12}$ Dari paham warga jemaat dapat disimpulkan bahwa penyandang disabilitas adalah orang-orang yang memiliki kekurangan baik secara fisik maupun mental sehingga sulit berpartisipasi secara aktif dalam lingkungannya.

\section{Gereja dan Pendampingan Terhadap Penyandang Disabilitas}

Para pelayan di Gereja Toraja Jemaat Kaero memahami bahwa penyandang disabilitas merupakan bagian dari jemaat yang sangat penting, mereka harus dihargai dan dilibatkan dalam pelayanan. Berangkat dari pemahaman itu, maka gereja mulai memberikan perhatian khusus kepada para penyandang disabilitas di Gereja Toraja jemaat Kaero. Mereka memberikan pelayanan secara bertahap seperti pelayanan diakonia baik berupa bantuan, pendampingan atau perkunjungan.

Menurut tuturan pendeta jemaat, sebelum pandemik covid-19 program pendampingan dilaksanakan secara rutin bahkan hampir setiap minggu. Pendeta bersama dengan diaken mengunjungi dan memberikan pembinaan-pembinaan untuk memotivasi agar para penyandang disabilitas tidak minder dengan orang-orang di sekitarnya. ${ }^{13}$ Kegiatan ini dianggap jauh lebih berdampak dibandingkan hanya sekedar memberi bantuan materi.

Dalam proses pendampingan yang dilakukan, para pelayan gereja mencoba mengenali potensi yang dimiliki para penyandang disabilitas untuk dapat dikembangkan dan dan diberdayagukanan oleh jemaat. Mereka yang dapat dilibatkan dalam pelayanan secara perlahan dimotivasi untuk mau terlibat atau mengambil bagian. Kepada para penyandang disabilitas berusaha ditumbuhkan keyakinan bahwa gereja menghargai keberadaan mereka. Oleh sebab itu, mereka pun harus merasa bangga dengan potensi

\footnotetext{
9 Jefry Huro, "Wawancara Oleh Penulis" (Kaero, 22 April021).

10 Ruben Basiang, "Wawancara Oleh Penulis” (Kaero, 22 April 2021).

11 Herlina Rampo, "Wawancara Oleh Penulis" (Kaero, 22 April 2021).

12 Daud Batu, "Wawancara Oleh Penulis" (Kaero, 30 Mei 2021).

13 Basiang, "Wawancara Oleh Penulis."
} 
dirinya. ${ }^{14}$ Dengan menumbuhkan sikap demikian, perlahan para penyandang disabilitas mulai terlibat dalam pelayanan baik sebagai pemain musik, maupun mengambil tanggungjawab sebagai koster gereja. ${ }^{15}$ Di samping pemberdayaan yang dilakukan langsung oleh jemaat, majelis gereja berusaha membangun jejaring dengan pemerintah dengan mengupayakan berbagai program pemberdayaan terhadap penyandang disabilitas. ${ }^{16}$

Majelis jemaat menyadari bahwa masih ada kelemahan dalam program yang dilakukan yakni hal itu belum berjalan maksimal. Alasan mendasar ialah jemaat memiliki beberapa program diakonia yang juga perlu mendapat perhatian, misalnya perkunjungan dan pendampingan kepada lansia, janda, duda. ${ }^{17}$ Akan tetapi kondisi pandemi covid-19 turut menghambat kegiatan perkunjungan padahal hal tersebut merupakan pendekatan utama dalam memotivasi penyandang disabilitas. Selain perkunjungan ke rumah, majelis jemaat juga memanfaatkan program katekisasi (dimana salah seorang penyandang disabilitas ikut terlibat) menjadi wadah pembinaan membangun interaksi sosial antara penyandang disabilitas dengan peserta lain yang normal. Melalui sikap ini diharapkan peserta katekisasi dapat membiasakan sikap saling menghargai. 18

Usaha lain yang dilakukan oleh majelis gereja ialah berusaha mengembangkan potensi dari penyandang disabilitas. Misalnya terhadap penyandang disabilitas yang memiliki keterampilan pangkas rambut. Untuk memberdayakan yang bersangkutan, majelis gereja bekerjasama dengan pemerintah daerah membuka tempat usaha pangkas rambut. 19

Program pendampingan dan pemberdayaan yang dilakukan majelis gereja sejauh ini mendapat respon baik dari jemaat. Jemaat menilai program itu cukup berhasil karena memberi dampak siginifikan terhadap kepercayaan dan keaktifan penyandang disabilitas. Namun tantangan lain juga muncul dari warga jemaat yang merasa tidak nyaman dengan program yang diakukan oleh gereja sehingga yang bersangkutan memutuskan tidak lagi aktif dalam pelayanan di gereja. ${ }^{20}$

\section{Pembahasan}

\section{Konsep diri}

Konsep diri adalah evaluasi individu mengenai diri sendiri, penilaian atau penafsiran mengenai diri sendiri. Konsep diri terbentuk karena adanya interaksi dengan orang-orang sekitarnya. Di sisi lain, konsep diri juga menyangkut terbentuk oleh persepsi

\footnotetext{
14 Ibid.

15 Rampo, "Wawancara Oleh Penulis."

16 Basiang, "Wawancara Oleh Penulis."

17 Ibid.

18 Rampo, "Wawancara Oleh Penulis"; Basiang, "Wawancara Oleh Penulis."

${ }^{19}$ Rampo, "Wawancara Oleh Penulis"; Basiang, "Wawancara Oleh Penulis."

${ }^{20}$ Basiang, "Wawancara Oleh Penulis."
} 
individu lain mengenai orang lain, tidak terlepas dari struktur, peran, dan status sosial yang disandang seorang individu. 21

Konsep diri bukanlah faktor yang dibawa sejak lahir, akan tetapi merupakan faktor yang dipelajari dan terbentuk dari pengalaman individu dalam berhubungan dengan individu lain. ${ }^{22}$ Konsep diri adalah hal yang sangat penting bagi kehidupan seseorang dan menentukan cara bertindak serta menghadapi kehidupan. Konsep diri merupakan sekumpulan keyakinan bahkan perasaan seseorang atas dirinya. ${ }^{23}$ Konsep diri merupakan aspek yang penting dalam diri seseorang karena konsep diri merupakan kerangka acuan dalam berinteraksi dengan lingkungan sekitar. ${ }^{24}$ Faktor konsep diri inilah yang tampil dengan jelas dan memengaruhi sikap pasif maupun aktif penyandang disabilitas dalam berinteraksi dengan orang lain. Konsep diri yang negatif muncul karena yang bersangkutan membandingkan keadaannya sewaktu normal dan setelah cacat. Pada kasus yang lain konsep diri negatif juga muncul karena perlakuan dari orang lain yang mengeksploitasi keterbatasannya sebagai jalan untuk mendiskriminasinya.

Konsep diri positif terbentuk karena adanya perhatian dan dukungan yang diperoleh dari keluarga maupun pendampingan oleh majelis gereja. Model pelayanan seperti ini dapat dikatakan sebagai dorongan moril kepada penyandang disabilitas. Keberadaan orang lain dibutuhkan untuk membangkitkan semangat di tengah perasaan yang menolak atau tidak mau menerima kenyataan. Melalui dukungan dari orang lain, seseorang akan merasa bahwa orang lain tidak memandang dirinya lebih buruk, bahkan menumbuhkan perasaan bahwa mereka diterima oleh orang lain. Hemat penulis dengan pola pikir demikian, maka rasa percaya diri dan menerima keadaan sendiri dapat bertumbuh.

\section{Perspektif Negatif dari Orang Lain}

Dari pemaparan data, tampak salah satu faktor yang menghambat penyandang disabilitas berinteraksi dalam kehidupan bermasyarakat dan berjemaat ialah saat orangorang disekitarnya menjadikan keterbatasan sebagai bahan untuk menilai dirinya secara negatif. Paradigma berpikir seperti ini yang juga harus digumuli majelis gereja di tengah pendampingan yang dilakukan terhadap penyandang disabilitas.

Melalui proses edukasi kepada semua warga jemaat bahkan warga masyarakat, diharapkan akses dalam berinteraksi dan berkreasi bagi penyandang disabilitas dapat diharapkan menjadi lebih luas dan mereka pun akan merasakan penerimaan yang sungguh-sungguh diberbagai lingkup komunitas.

21 Yudit Oktaria Kristiani Pardede. “Konsep Diri Anak Jalanan Usia Remaja” Jurnal Psikologi vol 1, No 2 (2008). Hal 147

22 Ibid.

${ }^{23}$ Andi Maulana Armas, Andi Alimuddin Unde, and Jeanny Maria Fatimah, "Konsep Diri Dan Kompetensi Komunikasi Penyandang Disabilitas Dalam Menumbuhkan Kepercayaan Diri Dan Aktualisasi Diri Di Dunia Kewirausahaan Kota Makassar," KAREBA : Jurnal Ilmu Komunikasi 6, no. 2 (December 25, 2017): 277, accessed June 2, 2021, http://journal-old.unhas.ac.id/index.php/kareba/article/view/5328.

24 Iskandar Zulkarnain, Sakhyan Asmara, and Raras Sutatminingsih, Membentuk Konsep Diri Melalui Budaya Tutur: Tinjauan Psikologi Komunikasi (Medan: Puspantara, 2020), 11. 
Edukasi yang baik terhadap warga jemaat dibutuhkan dalam rangka mengubah persepsi mereka terhadap penyandang disabilitas. Bukan menjadikan mereka objek yang di pandang rendah maupun sebagai saingan dalam partisipasi pada kegiatan di jemaat (merujuk pada kasus yang telah diungkap dalam pemaparan data). Penting untuk menempatkan penyandang disabilitas sebagai mitra dalam kehidupan berjemaat dan dalam keterlibatan bersama dalam pelayanan di gereja.

\section{Program Pemberdayaan Jemaat}

Pemberdayaan merupakan suatu upaya meningkatkan kemampuan individu khususnya kelompok yang rentan atau lemah sehingga individu memiliki kekuatan ataupun kemampuan untuk memenuhi kebutuhan dasar. Melalui aksi pemberdayaan individu atau kelompok diharapkan dapat bebas dari kelaparan, kebodohan, kesakitan. Kegiatan pemberdayaan dimaksudkan untuk menjangkau sumber-sumber yang produktif sehingga individu dapat meningkatkan pendapatannya bahkan memperoleh barang-barang dan jasa yang dibutuhkan, berpartisipasi dalam pembangunan serta pengambilan keputusan.25 ${ }^{25}$ Berdasarkan pemahaman tersebut dapat dikatakan pemberdayaan merupakan upaya komprehensif agar seseorang atau kelompok dapat memiliki kemampuan dan atau mengelola potensinya supaya dapat berdaya guna di tengah masyarakat.

Usaha pemberdayaaan perlu memperhitungkan berbagai aspek baik itu potensi, faktor-faktor yang turut memengaruhi baik internal maupun eksternal, serta strategi yang tepat. Pemberdayaan bukan sekedar memberi petunjuk tentang apa yang perlu dilakukan dan bagaimana melakukannya? Sangat penting dicapai dalam pemberdayaan adalah menyadarkan orang yang didampingi, mendorong mereka mengambil keputusan yang tepat, yang dapat membantunya keluar dari situasi sulit yang dihadapi. Apabila faktor ini diabaikan, maka orang yang didampingi hanya akan menjadi pribadi yang bergantung pada keberadaan orang lain.

Pada bidang pelayanan gereja, program pemberdayaan bagian dari tugas panggilan dan perutusan gereja. Gereja dipanggil untuk memberitakan kabar keselamatan dari Allah atau Kerajaan Allah. Panggilan hidup menggereja ini diterjemahkan dalam berbagai bentuk aksi pelayanan (diakonia). Melalui diakonia, gereja perlu terus menerus menyuarakan dan menampakkan tugas profetisnya, membongkar sistem yang membelenggu, memulihkan citra manusia sebagai gambar Allah dan mengembangkan kehidupan menjadi lebih baik. ${ }^{26}$ Dengan merujuk praksis diakonia yang dilakukan Yesus dalam kitab Injil, Josef P. Widyaatmadja menegaskan hubungan erat antara diakonia dan missio dei. Dalam pelayanan-Nya, Yesus tidak hanya menyembuhkan yang sakit dan lemah namun memberdayakan mereka sehingga menjadi pribadi yang tidak bergantung pada orang lain. Dalam karya diakonia, Yesus sedang mewujudkan 2005), 96.

${ }^{25}$ E Suharto, Mengembangkan Masyarakat Memberdayakan Rakyat (Bandung: Rafika Aditama,

${ }^{26}$ Norbertus Jegalus, “Tanggung Jawab Awam Dalam Perutusan Diakonia Gereja," LUMEN VERITATIS: Jurnal Teologi dan Filsafat 10, no. 2 (2020): 157-158. 
manusia dan dunia baru. ${ }^{27}$ Diakonia menuntut aspek perubahan hidup menuju kehidupan yang bermartabat sebagaimana citra diri manusia di hadapan Allah. Kehidupan baru yang dijalani menawarkan ruang kebebasan, penerimaan dan kehidupan yang menampakkan damai sejahtera Allah.

Dalam konteks penyandang disabilitas dari penelitian ini, pelayanan yang mengarah pada pemberdayaan dibutuhkan untuk meningkatkan partisipasi mereka pada berbagai bidang kehidupan. Membuat mereka menjadi pribadi yang tidak selalu bergantung kepada orang lain, dan meningkatkan derajat serta fungsi sosialnya di tengah masyarakat. $^{28}$ Pemberdayaan kaum disabilitas sebagai proses, cara, untuk memberdayakan, ataupun kemampuan dalam melakukan sesuatu untuk bertindak demi mencapai tujuan. ${ }^{29}$

Pemberdayaan merupakan upaya untuk mendorong, memotivasi seseorang agar orang tersebut memiliki kemampuan atau diberdayakan dalam menentukan pilihan hidupnya. Pemberdayaan menunjuk kepada kemampuan seseorang termasuk penyandang disabilitas agar mereka memiliki kemampuan atau kekuatan memenuhi kebutuhan dasarnya serta menjangkau berbagai sumberdaya yang dibutuhkan untuk memperbaiki taraf hidupnya. Di samping itu, setiap aksi pemberdayaan harus memberi ruang penerimaan kepada penyandang disabilitas untuk berpartisipasi dalam pelayanan gereja dan masyarakat.

Penyandang disabilitas pada konteks penelitian ini berhadapan dengan dua tantangan: Pertama, mereka harus mengalahkan adanya sikap diskriminatif dan usaha segelintir oknum yang tidak ingin penyandang disabilitas berpartisipasi dalam kegiatan gereja. Kedua, sikap inferior karena merasa lemah dan tidak normal seperti orang lain. Kondisi inilah yang menurut hemat kami sangat disadari oleh majelis Gereja Jemat Kaero ketika mereka mulai mengadakan pelayanan diakonia kepada penyandang disabilitas.

Umumnya model diakonia dalam gereja diklasifikasikan menjadi tiga yakni diakonia karitatif, diakonia reformatif dan diakonia transformatif. ${ }^{30}$ Diakonia karitatif dilakukan dalam bentuk pemberian bantuan berupa materi makanan dan minuman kepada mereka yang membutuhkan. Diakonia ini tetap penting sekalipun efek dari aksi ini hanya dirasakan sesaat dan tidak benar-benar memecahkan persoalan yang dihadapi. Diakonia reformatif berorientasi kepada pembangunan berbagai akses yang dianggap dapat meningkatkan kehidupan masyarakat yang bergumul dengan penderitaan. Pada model diakonia ini diharapkan semua orang dapat berpartisipasi dalam pembangunan bersama. Namun model ini kurang memberi perhatian kepada hal-hal substansial terkait

\footnotetext{
27 Josef P. Widyatmadja, Yesus Dan Wong Cilik: Praksis Diakonia Transformatif Dan Teologi Rakyat Di Indonesia (Jakarta: BPK Gunung Mulia, 2010), 10.

28 Sy Nurul Syobah, "Pemberdayaan Penyandang Disabilitas Di Provinsi Kalimantan Timur," NUANSA: Jurnal Penelitian Ilmu Sosial dan Keagamaan Islam 15, no. 2 (December 18, 2018): 255, accessed June 2, 2021, http://ejournal.iainmadura.ac.id/index.php/nuansa/article/view/2057.

${ }^{29}$ Lorentius Goa, "Pemberdayaan Penyandang Disabilitas Melalui Balai Latihan Kerja Bhakti Luhur," Jurnal Pelayanan Pastoral 1, no. 1 (2020): 42, http://e-journal.stpipi.ac.id/index.php/jpp/article/view/142.

30 Widyatmadja, Yesus Dan Wong Cilik: Praksis Diakonia Transformatif Dan Teologi Rakyat Di Indonesia,31.
} 
persoalan yang dihadapi oleh mereka yang menderita. Model diakonia transformatif dapat dikatakan sebagai model pemberdayaan. Model ini menitikberatkan pada usaha penyadaran kepada mereka yang menderita terhadap berbagai hal yang membelenggu dan selanjutnya menggerakkan mereka untuk mengembangkan potensi yang ada pada dirinya, sehingga mereka menjadi pribadi yang tidak bergantung kepada orang lain.

Jika mengacu kepada tiga model pelayanan diakonia tersebut, maka dapat dikatakan bahwa gereja mulai melaksanakan model-model tersebut secara komprehensif. Melalui bantuan kepada penyandang disabilitas gereja mempraktekan model diakonia karitatif. Tentu hal ini dibutuhkan untuk mendukung kebutuhan seharihari yang bersifat sementara. Sementara itu, melalui bantuan membangun tempat usaha pangkas rambut majelis gereja mempraktekkan model reformatif. Aksi menuju model diakonia transformatif tampak dari perkunjungan dan pendampingan yang dilakukan gereja. Gereja berusaha membongkar konsep diri negatif yang telah menjebak penyandang disabilitas pada posisi pasif, minder atau bahkan putus asa. Menurut hemat penulis, tindakan itu sangat dibutuhkan dalam mengatasi persoalan utama dari penyandang disabilitas. Sekalipun lingkungan sekitar mulai terbuka dan memberikan akses interaksi yang lebih luas, tetapi kalau penyandang disabilitas tidak mengalami perubahan pola pikir, maka mereka tetap akan merasa tidak bebas berinteraksi dan berkreasi. Lewat perkunjungan itu, mulai terungkap potensi yang dimiliki oleh penyandang disabilitas, yang selanjutnya menjadi jalan bagi gereja dalam memberdayakan mereka.

Majelis gereja perlu mendapat apresiasi karena melalui perkunjungan mereka berhasil mengubah konsep diri negatif yang sudah terlanjur melekat dalam benak dari penyandang disabilitas. Melalui perkunjungan, terlihat empati kepada yang lemah (penyandang disabilitas). Pesan itulah yang diterima dan mendapat respon positif sehingga penyandang disabilitas mau terbuka menceritakan keadaan, pengalamannnya dan mendorong munculnya keinginan untuk berubah. Perkunjungan memperlihatkan bahwa penyandang disabilitas memiliki tempat di tengah pelayanan gereja sehingga menjadi jalan untuk mengalahkan perasaan inferior atau minder.

Usaha yang dilakukan gereja memperlihatkan bahwa gereja mendorong supaya kehidupan penyandang disabilitas mengalami perubahan dan menjadikan mereka sebagai pribadi yang mandiri dan mengembangkan potensi dirinya. Namun demikian, tetap perlu meningkatkan upaya pendampingan terhadap penyandang disabilitas misalnya berkenaan dengan pembinaan mentalitas sehingga mereka menjadi pribadi yang kuat saat berhadapan dengan masalah. Di sisi lain program pemberdayaan terhadap penyandang disabilitas perlu mendapat daya dukung dari keluargaa. Oleh karena itu pendampingan pendampingan dan penguatan juga perlu dilakukan kepada keluarga secara intens. Keluarga yang akan paling sering berinteraksi dan mendampingi anggota keluarganya yang diabilitas. Dinie Ratri Desiningrum dalam penelitiannya memperlihatkan secara psikologis keberadaan keluarga sangat dibutuhkan saat mendampingi mereka yang berkebutuhan khusus di dalam proses beradaptasi dengan 
lingkungannya, memecahkan masalah serta dalam menghadapi masa-masa kritis. Oleh karena itu orang tua juga perlu dibekali dengan berbagai bentuk pengetahuan, serta dibimbing untuk lebih bersikap toleransi dan sabar. ${ }^{31}$

Faktor lain yang perlu dilakukan gereja ialah mencoba meminimalisir faktorfaktor eksternal yang menimbulkan tekanan terhadap penyandang disabilitas, yakni memberikan edukasi kepada masyarakat atau warga jemaat. Sebagaimana terungkap pada salah satu penyandang disabilitas, ejekan yang diterima beberapa waktu lalu telah membentuk perasaan bahwa orang-orang disekitar menolaknya. Edukasi perlu dilakukan supaya pemberdayaan tidak hanya menjadi program pelayanan gereja semata, tetapi menjadi penggerak bagi semua orang untuk berempati, menerima dan mendorong mereka yang disabilitas untuk tetap memiliki keinginan maju dan berinteraksi dengan baik tanpa perlu mengkuatirkan pandangan orang tentang kondisi tubuhnya.

\section{Kesimpulan}

Penyandang Disabilitas adalah mereka yang memiliki kekurangan bukan hanya fisik tetapi juga mental. Penyandang disabilitas adalah orang-orang yang memiliki keterbatasan dalam berinteraksi dengan lingkungannya dan sulit berpartisipasi penuh dan efektif seperti orang-orang normal yang ada di sekitar. Penyandang disabilitas merupakan sebuah kondisi keterbatasan dalam melaksanakan suatu aktivitas karena adanya kekurangan baik itu fisik ataupun mental. Jadi, penyandang disabilitas adalah orang-orang yang memiliki kekurangan baik itu secara fisik pun mental sehingga sulit berpartisipasi secara aktif dalam kehidupan seperti orang-orang di lingkungan sekitarnya.

Sehubungan dengan keberadaan penyandang disabilitas di Gereja Toraja Jemaat Kaero, tampak bahwa gereja telah berupaya memberikan perhatian kepada mereka dan berusaha memberikan berbagai bentuk pelayanan diakonia baik yang sifatnya karitatif, reformatif dan transformatif. Majelis gereja menjadikan program perkunjungan sebagai tahap awal dalam proses pemberdayaan. Dalam perkunjungan, majelis gereja mencoba mengarahkan penyandang disabilitas supaya mengalahkan konsep diri negatif untuk kemudian mulai berpikir positif di tengah keterbatasan yang dimiliki. Hal itu terbukti berhasil dan mendorong kesadaran akan potensi diri dan keberanian untuk berinteraksi dengan orang lain. Dengan pola pikir yang terbuka, gereja mulai memberikan daya dukung dengan memfasilitasi mereka supaya memiliki pekerjaan. Cara ini menolong penyandang disabilitas menjadi lebih mandiri. Usaha ini perlu diperkuat oleh majelis gereja dengan mengadakan perkunjungan dan edukasi kepada keluarga bahkan seluruh anggota masyarakat.

\section{Referensi}

Armas, Andi Maulana, Andi Alimuddin Unde, and Jeanny Maria Fatimah. "KONSEP DIRI DAN KOMPETENSI KOMUNIKASI PENYANDANG DISABILITAS DALAM

31 Dinie Ratri Desinigrum, “Analisis Kebutuhan Pada Keluarga Yang Memiliki Anak Kebutuhan Khusus," in Pemberdayaan Keluarga Dalam Perspektif Psikologi, ed. Endang Sri Indrawati and Muhammad Zulfa Alfarugy (Semarang: Fakultas Psikologi Undip, 2018), 114. 
MENUMBUHKAN KEPERCAYAAN DIRI DAN AKTUALISASI DIRI DI DUNIA KEWIRAUSAHAAN KOTA MAKASSAR." KAREBA : Jurnal Ilmu Komunikasi 6, no. 2 (December 25, 2017): 277. Accessed June 2, 2021. http://journalold.unhas.ac.id/index.php/kareba/article/view/5328.

Banawiratma, J.B. "Proses Teologi Sosial." In Aspek-Aspek Teologi Sosial, edited by J.B. Banawiratma, 11-15. Yogyakarta: Kanisius, 1992.

Basiang, Ruben. “Wawancara Oleh Penulis," 2021.

Batu, Daud. "Wawancara Oleh Penulis," 2021.

Desinigrum, Dinie Ratri. "Analisis Kebutuhan Pada Keluarga Yang Memiliki Anak Kebutuhan Khusus." In Pemberdayaan Keluarga Dalam Perspektif Psikologi, edited by Endang Sri Indrawati and Muhammad Zulfa Alfarugy, 106-121. Semarang: Fakultas Psikologi Undip, 2018.

Goa, Lorentius. "Pemberdayaan Penyandang Disabilitas Melalui Balai Latihan Kerja Bhakti Luhur." Jurnal Pelayanan Pastoral 1, no. 1 (2020): 40-48. http://ejournal.stp-ipi.ac.id/index.php/jpp/article/view/142.

Hayon, Yohanes Wele. "Disabilitas Dalam Teologi Katolik: Dari Liberalisme Dan Politik Kaish." Inklusi: Journal of Disability Studies 6, no. 2 (2019): 235-258.

Huro, Jefry. "Wawancara Oleh Penulis," 2021.

Jegalus, Norbertus. "Tanggung Jawab Awam Dalam Perutusan Diakonia Gereja." LUMEN VERITATIS: Jurnal Teologi dan Filsafat 10, no. 2 (2020): 139-163.

Noor, Muhammad Hidayat. "Agama Dan Pemberdayaan Difabel: Studi Komparatif Terhadap Yayasan Kesejahteraan Tunanetra Islam (Yaketunis) Dan Pusat Rehabilitasi Yayasan Kristen Untuk Kesejahteraan Umum (Yakkum)." Religi: Jurnal Studi Agama-agama XII, no. 1 (2016): 17-37.

Rampo, Herlina. "Wawancara Oleh Penulis," 2021.

Suharto, E. Mengembangkan Masyarakat Memberdayakan Rakyat. Bandung: Rafika Aditama, 2005.

Syobah, Sy Nurul. "Pemberdayaan Penyandang Disabilitas Di Provinsi Kalimantan Timur." NUANSA: Jurnal Penelitian Ilmu Sosial dan Keagamaan Islam 15, no. 2 (December 18, 2018): 251. Accessed June 2, 2021. http://ejournal.iainmadura.ac.id/index.php/nuansa/article/view/2057.

Teddywono, Innawati. "Pemuridan Bagi Jemaat Penyandang Disabilitas." SANCTUM DOMINE: JURNAL TEOLOGI 10, no. 1 (December 29, 2020): 17-34. Accessed June 2, 2021. http://sosbud.kompasiana.com/2014/06/14/disabil.

Thohari, Slamet. "Pandangan Disabilitas Dan Aksesibilitas Fasilitas Publik Bagi Penyandang Disabilitas Di Kota Malang." Indonesian Journal of Disability Studies 1, no. 1 (2014): 27-37. Accessed June 2, 2021. https://ijds.ub.ac.id/index.php/ijds/article/view/38.

Widyatmadja, Josef P. Yesus Dan Wong Cilik: Praksis Diakonia Transformatif Dan Teologi Rakyat Di Indonesia. Jakarta: BPK Gunung Mulia, 2010.

Zulkarnain, Iskandar, Sakhyan Asmara, and Raras Sutatminingsih. Membentuk Konsep Diri Melalui Budaya Tutur: Tinjauan Psikologi Komunikasi. Medan: Puspantara, 2020. 